\title{
Interactive comment on "Identifying a regional aerosol baseline in the Eastern North Atlantic using collocated measurements and a mathematical algorithm to mask high submicron number concentration aerosol events" by \\ Francesca Gallo et al.
}

\section{Francesca Gallo et al.}

fgallo@lanl.gov

Received and published: 14 May 2020

We thank Anonymous Referee \#2 for reviewing the manuscript and for the constructive criticism and detailed suggestions. Please, find our point-by-point responses in the attached pdf file.

Please also note the supplement to this comment: 
https://www.atmos-chem-phys-discuss.net/acp-2020-49/acp-2020-49-AC2supplement.pdf

ACPD

Interactive comment on Atmos. Chem. Phys. Discuss., https://doi.org/10.5194/acp-2020-49, 2020.

Interactive

comment 